\section{STIMULATION OF THE PRODUCTION OF MACROLIDE ANTIBIOTICS BY MAGNESIUM PHOSPHATE AND RELATED INSOLUBLE MATERIALS*}

Sir:

Biosynthesis of antibiotics is often regulated by carbon catabolites, nitrogen catabolites, phosphates and other metabolites ${ }^{1,2)}$. Recent advances revealed the biochemical bases of the carbon catabolite regulation ${ }^{3,4}$ and the phosphate regulation ${ }^{5,6)}$. High production of antibiotics has generally been achieved by cultivating the producing organisms in media containing slowly utilized carbon and/or nitrogen sources or under conditions which allow a slow supply of these nutrients ${ }^{1)}$. Although several papers suggested nitrogen catabolite regulation in the biosynthesis of antibiotics ${ }^{1,2)}$, the importance and the methods for its relief have not been discussed in relation to antibiotic production. Recently, it: was reported ${ }^{7)}$ that microbial conversion of glycine to L-serine was stimulated by magnesium phosphate $(\mathrm{MgP})$, and the relevance of the stimulation to the nitrogen catabolite regulation was postulated, based upon the fact that the ammonium ion concentration in the culture broth was depressed in the presence of MgP. In view of this observation it was of interest to examine if $\mathrm{MgP}$ might exert a similar effect on the production of antibiotics. The marked stimulation of leucomycin production by $\mathrm{MgP}$ has been reported from this laboratory ${ }^{8)}$. The present communication describes the stimulation of the production of other macrolide antibiotics, spiramycin and tylosin, in the presence of $\mathrm{MgP}$ and related insoluble materials.

Streptomyces kitasatoensis KA-429 (a mutant strain of the original leucomycin producer NRRL 2486), S. ambofaciens ATCC 23877 (a spiramycin producer), and $S$. fradiae KA-427 (a tylosin producer) were cultivated at $27^{\circ} \mathrm{C}$ with reciprocal shaking (240 strokes/min) in a large test tube $(20 \mathrm{~cm} \times 2 \mathrm{~cm})$ containing $10 \mathrm{ml}$ of a complex medium or chemically defined medium. The compositions of these media are given in the footnote of Table 1. Antibiotic titer was estimated by conventional paper disc method using

Table 1. Stimulation of the production of the macrolide antibiotics, leucomycin, spiramycin and tylosin, by magnesium phosphate and related materials.

\begin{tabular}{|c|c|c|c|c|c|}
\hline \multirow{2}{*}{ Antibiotic } & \multicolumn{2}{|l|}{ Addition } & \multirow{2}{*}{$\begin{array}{c}\text { Basal } \\
\text { medium } \\
\text { No. }\end{array}$} & \multicolumn{2}{|c|}{ Antibiotic produced $(\mu \mathrm{g} / \mathrm{ml})$} \\
\hline & Compound & Amount $(\%)$ & & No addition & Addition \\
\hline \multirow[t]{4}{*}{ Leucomycin } & $\mathrm{Mg}_{3}\left(\mathrm{PO}_{4}\right)_{2} \cdot 8 \mathrm{H}_{2} \mathrm{O}(=\mathrm{MgP})$ & 1 & 1 & 270 & 900 \\
\hline & $\left.\mathrm{NH}_{4} \mathrm{MgPO}_{4} \cdot 6 \mathrm{H}_{2} \mathrm{O}^{2}\right)$ & 1 & 1 & $85^{\mathrm{b})}$ & $840^{\text {a) }}$ \\
\hline & $\mathrm{Mg}_{3}\left(\mathrm{PO}_{4}\right)_{2} \cdot 8 \mathrm{H}_{2} \mathrm{O}$ & 1 & 2 & 480 & 2,600 \\
\hline & " & 1 & 3 & $<10$ & 960 \\
\hline \multirow[t]{5}{*}{ Spiramycin } & $\mathrm{Mg}_{3}\left(\mathrm{PO}_{4}\right)_{2} \cdot 8 \mathrm{H}_{2} \mathrm{O}$ & 3 & 1 & $<10$ & 150 \\
\hline & $\mathrm{Ca}_{3}\left(\mathrm{PO}_{4}\right)_{2}$ & 1 & 1 & $<10$ & 165 \\
\hline & $\mathrm{NH}_{4} \mathrm{MgPO}_{4} \cdot 6 \mathrm{H}_{2} \mathrm{O}^{\mathrm{a})}$ & 1 & 1 & $<10^{\mathrm{b})}$ & $270^{\text {a) }}$ \\
\hline & $\mathrm{Ca}_{3}\left(\mathrm{PO}_{4}\right)_{2}$ & 0.5 & 4 & 200 & 400 \\
\hline & $\mathrm{Na}_{3} \mathrm{P}_{2} \mathrm{~W}_{12} \mathrm{O}_{43} \cdot 18 \mathrm{H}_{2} \mathrm{O}$ & 1 & 4 & 200 & 340 \\
\hline Tylosin & $\mathrm{NH}_{4} \mathrm{MgPO}_{4} \cdot 6 \mathrm{H}_{2} \mathrm{O}^{\mathrm{a})}$ & 1 & 1 & $86^{\mathrm{b})}$ & $340^{\text {a) }}$ \\
\hline
\end{tabular}

a) $\mathrm{NH}_{4} \mathrm{MgPO}_{4} \cdot 6 \mathrm{H}_{2} \mathrm{O}$ was used as sole nitrogen source.

b) Ammonium lactate was used as sole nitrogen source.

c) Medium 1 contained: $3 \%$ glycerol, $0.5 \%$ glucose, $1 \%$ ammonium lactate, $0.1 \% \mathrm{MgSO}_{4} \cdot 7 \mathrm{H}_{2} \mathrm{O}$, $0.01 \% \mathrm{~K}_{2} \mathrm{HPO}_{4}, 0.5 \% \mathrm{CaCO}_{3}$ and $1 \mathrm{ml}$ of trace metal solution* per liter, $\mathrm{pH} 7.2$. *Trace metal solution contained (each $1 \mathrm{~g} /$ liter) $\mathrm{FeSO}_{4} \cdot 7 \mathrm{H}_{2} \mathrm{O}, \mathrm{MnCl}_{2} \cdot 4 \mathrm{H}_{2} \mathrm{O}, \mathrm{ZnSO}_{4} \cdot 7 \mathrm{H}_{2} \mathrm{O}, \mathrm{CuSO}_{4} \cdot 5 \mathrm{H}_{2} \mathrm{O}$ and $\mathrm{CoCl}_{2} \cdot 2 \mathrm{H}_{2} \mathrm{O}$.

Medium 2 contained: $2 \%$ glucose, $0.5 \%$ peptone, $0.3 \%$ dried yeast cells, $0.5 \%$ meat extract, $0.5 \% \mathrm{NaCl}$ and $0.3 \% \mathrm{CaCO}_{3}, \mathrm{pH} 7.3$.

Medium 3 contained: $1 \%$ glycerol, $1 \%$ soybean meal, $0.3 \% \mathrm{NaCl}, \mathrm{pH} 6.5$.

Medium 4 contained: $1 \%$ glucose, $1 \% \mathrm{NaNO}_{3}, 0.5 \% \mathrm{NaCl}$ and $0.3 \% \mathrm{CaCO}_{3}, \mathrm{pH} 7.0$.

* Bioconversion and biosynthesis of 16-membered macrolide antibiotics. XIX. A part of this study was presented at the 100th Annual Meeting of the Pharm. Soc. Japan, 1980 (Tokyo). 
Sarcina lutea PCI 1001 as test organism (nutrient agar, $37^{\circ} \mathrm{C}, 20$ hours). The antibiotic titers were assayed daily. As summarized in Table 1, the production of the three macrolide antibiotics was enhanced 2- to 100 -fold in the presence of $\mathrm{MgP}$ or related substances. The extent of stimulation depended on the basal media, the microorganisms used and the compounds added. The major component of the antibiotics (leucomycin, $\mathrm{A}_{3}$, spiramycin II (and III) and tylosin) remained the same in the presence or in the absence of the additions as analyzed by thin-layer chromatography described in the previous papers ${ }^{9 \sim 11}$. The increase in mycelial growth was also notable especially in chemically defined media: it nearly doubled in the presence of MgP for leucomycin production; on the other hand, the increase in the antibiotic titers was always more than 2-fold, suggesting a net increase of the antibiotic formation.

In the leucomycin fermentation, the ammonium ion concentration of the supernatant of the MgP-supplemented culture was lowered in both chemically defined ${ }^{8)}$ and complex media, whereas the sediments contained considerable amounts of ammonia. In separate experiments, high concentrations of ammonium ions were found to inhibit the leucomycin production, while $\mathrm{pH}$ control of the culture medium slightly increased the leucomycin titers.

From these results, it is supposed that a limited supply of ammonium ions caused by $\mathrm{MgP}$ led to the high production of leucomycin as well as spiramycin and tylosin. In support of this view ammonium magnesium phosphate $\left(\mathrm{NH}_{4} \mathrm{MgPO}_{4}\right.$. $6 \mathrm{H}_{2} \mathrm{O}$, an insoluble nitrogen source) also gave rise to an elevation of the production of these antibiotics (Table 1).

\section{Acknowledgment}

The helpful technical assistance of Mr. Н. КовAYASHI is greatly appreciated.

\section{SATOSHI ŌMURA YOSHITAKE TANAKA HARUO TANAKA YÖKO TAKAHASHI YUZURU IWAI}

School of Pharmaceutical Sciences, Kitasato University and The Kitasato Institute, Minato-ku, Tokyo 108, Japan
(Received July 19, 1980)

\section{References}

1) Drew, S. W. \& A. L. Demain: Effect of primary metabolites on secondary metabolism. Ann. Rev. Microbiol. 31: 343 356, 1977

2) NaKAyAma, K.: Regulation of microbial secondary metabolism. Amino acid \& Nucleic Acid 36: 1 33, 1977

3) Gallo, M. \& E. Katz: Regulation of secondary metabolite biosynthesis: Catabolite repression of phenoxazinone synthetase and actinomycin formation by glucose. J. Bacteriol. 109: $659 \sim 667,1972$

4) Hinnen, A. \& J. Nuesch: Enzymatic hydrolysis of cephalosporin $\mathrm{C}$ by an extracellular acetylhydrolase of Cephalosporium acremonium. Antimicr. Agents \& Chemoth. 9: 824 830, 1976

5) Walker, M. W. \& J. B. Walker: Streptomycin biosynthesis. Separation and substrate specificities of phosphatases acting on guanidinodeoxy-scyllo-inositol phosphate and streptomycin-(streptidino)phosphate. J. Biol. Chem. 246: $7034 \sim 7040,1971$

6) Vu-Trong, K.; S. Bhuwapathanapun \& P. P. GraY: Metabolic regulation in tylosin-producing Streptomyces fradiae: Regulatory role of adenylate nucleotide pool and enzymes involved in biosynthesis of tylonolide precursors. Antimicr. Agents \& Chemoth. 17: 519 525, 1980

7) TANAKA, Y.; K. ARAKI \& K. NaKayama: Stimulation of microbial conversion of glycine to L-serine by magnesium phosphate. J. Ferment. Technol. 58: 189 196, 1980

8) Ōmura, S.; Y. Tanaka, H. Tanaka, Y. Takahashi, Y. IwaI \& C. Kitao: Stimulation of leucomycin production by magnesium phosphate and its relevance to nitrogen catabolite regulation. Antimicr. Agents \& Chemoth. (in press)

9) Kitao, C.; J. Miyazawa \& S. ŌMura: Induction of the bioconversion of leucomycins by glucose and its regulation by butyrate. Agr. Biol. Chem. 43: 833 839, 1979

10) ŌMura, S.; C. Kitao, H. Hamada \& H. Ikeda: Bioconversion and biosynthesis of 16-membered macrolide antibiotics. X. Final steps in the biosynthesis of spiramycin, using enzyme inhibitor: cerulenin. Chem. Pharm. Bull. 27: 176 182, 1979

11) Ōmura, S.; C. Kitao, J. Miyazawa, H. Imai \& H. TAKESHIMA: Bioconversion and biosynthesis of 16-membered macrolide antibiotic, tylosin, using enzyme inhibitor: cerulenin. J. Antibiotics 31: 254 256, 1978 